\title{
SUSTAINABILITY STRATEGIES OF INDONESIAN MEGA-DAIRY FARM BUSINESS: A CASE OF GREENFIELDS INDONESIA
}

\author{
Adhitya Rahmana ${ }^{* 1}$, Arief Daryanto*), and Siti Jahroh*) \\ *) School of Business, Bogor Agricultural University \\ Raya Pajajaran Street, Bogor 16151
}

\begin{abstract}
The increase of milk import in Indonesia can be anticipated through the development of dairy farms based on mega-farm. Indonesia has already got dairy farms that adopt the mega-farm, one of which is the Greenfields Indonesia (GFI). GFI has become an export-oriented company, so GFI needs to pay attention to its sustainability on their business processes. This study was conducted at Dairy farm of Greenfields Indonesia. The purpose of this study was to analyze the business sustainability factors and to evaluate the factors of GFI dairy farming business based on the success factor of sustainability relation structure. The combination of delphi fuzzy and DEMATEL (Decision-Making Trial and Evaluation Laboratory) was used for data processing. The research results showed that the standardization of the company's management system was the first priority based on the relation structure. The priority could affect the resilience of farm models that depended on manure management impact and create animal care through the availability of management of feed and drinking water.
\end{abstract}

Keywords: dairy farming, sustainable business development, fuzzy delphi method, dematel, management system

Abstrak: Peningkatan impor susu di Indonesia dapat diantisipasi melalui peternakan sapi perah berbasis mega-farm. Peternakan sapi perah berbasis mega-farm memiliki resiko terhadap aspek lingkungan dan sosial, sehingga diperlukan strategi keberlanjutan untuk mengantisipasi resiko-resiko ini. Indonesia sudah memiliki peternakan sapi perah yang mengadopsi mega-farm terbesar saat ini yaitu Greenfields Indonesia (GFI). Studi ini dilakukan di peternakan sapi perah Greenfields Indonesia. Tujuan dari penelitian ini adalah untuk menganalisis faktor keberlanjutan peternakan dan mengevaluasi faktor keberhasilan keberlanjutan GFI berdasarkan struktur hubungannya. Kombinasi delphi fuzzy dan dematel (decision-making trial and evaluation laboratory) digunakan untuk pengolahan dan analisis data. Hasil penelitian dapat menunjukkan bahwa standarisasi sistem manajemen perusahaan merupakan prioritas pertama berdasarkan struktur hubungan. Prioritas ini dapat mempengaruhi ketahanan model peternakan sapi perah yang bergantung pada pengelolaan limbah ternak, sehingga berdampak terciptanya kepedulian hewan melalui pengelolaan ketersediaan pakan dan air minum.

Kata kunci: peternakan sapi perah, pengembangan usaha yang berkelanjutan, metode delphi fuzzy, dematel, sistem manajemen

\footnotetext{
${ }^{1}$ Corresponding author:

Email: adhitya.rahmana@gmail.com
} 


\section{INTRODUCTION}

The sub-sector of Indonesian dairy farms is dominated by rural dairy farm (Sulistyati et al. 2013). The dairy cows of rural dairy farmers have a population below 10 cows with average milk production of 8-12 liters/day in two times milking. This condition makes Indonesia lack in domestic milk supply, and thus increase milk import as raw material of milk processing industries. Projected output from the Ministry of Agriculture (2016) increased until 2020, reaching 1.14 million tons. This increase should be accompanied by the domestic milk production, so that Indonesia can reduce milk imports which currently reaches $80 \%$.

The current reduction in milk imports can be anticipated through the development of mega-dairy farm concept in Indonesia. Mega-dairy farm concept or factory farm concept is the concept of a very large-scale commercial dairy farm, typically intensive farming of thousands of cows in indoor facilities. One of the concepts of mega dairy farm or factory dairy farm in Indonesia is a dairy farm owned by Greenfields Indonesia (GFI). The company produces dairy products, all of whose fresh milk supplies come from dairy farms that are managed in an integrated manner. The condition of GFI dairy farms is still under development, and it still expands new dairy farm sites. The company develops its dairy farm business to reach a population of 24,000 heads. The bigger the dairy farm, the greater the economy's efficiency is. Research on the efficiency of dairy farming business states that the greater the scale of livestock business will be the greater the level of technical efficiency (Asmara et al. 2016). Therefore, the GFI dairy farm based on this mega-dairy farm concept can have a positive impact to assist the government in increasing domestic milk production.

In spite of the positive impact, the existence of GFI dairy farms has also a negative impact due to dairy farm activities based on this mega dairy farm concept. Opinions in various developed countries argue that mega-dairy farms have negative environmental impacts (Schmalzried and Fallon, 2010) on animal welfare (Dalton, 2016) and local farmers (Ford, 2010). GFI as a company that has a mega dairy farm in Indonesia also has the same negative impact as in many developed countries. GFI problems of business activities are very possible to produce environmental pollution due to the dumping of manure in lagoon, to increase dairy cow mortality due to herd management incompatibility, and to arouse public's assumption that mega dairy farm can shut down the activities of rural dairy farmer because they cannot compete with large-scale farms.

This condition must be addressed by the company through reactive and proactive social responsibility in order to support sustainable business. Dairy farms that have export markets need to carry out their social responsibilities reactively through various activities that are philanthropic, while social responsibility is done proactively by integrating business activities that involve the society. This research is important to undertake in order to assess the ability of sustainability as a corporate social responsibility and sustainability strategy as a necessary effort to create mutual benefits. The creation of mutual benefits is a company policy that combines the obligations of a business to generate profit and social responsibility (Daryanto, 2017).

Previous research on sustainable dairy farming is still studied slightly. Research by Konovalchuk et al. (2008) stated that the initiation of sustainable dairy farm is prioritized to create environmental sustainability through the management of air quality control. Another study on sustainable dairy farming is the study by Meul et al. (2009) that stated that the integration of dairy farming on dairy farms in Flemish is an integration of economic, ecological and social sustainability. Sustainable dairy farming in Orhan and Yasar (2010) studies shows that sustainable dairy farm qualifications are examined on the basis of farm size, farming and milking mechanization. These three studies show that there is no research on sustainable dairy farm that is evaluated based on the priority and structure of the relationship. Therefore, this research is very important for the development of sustainability in the field of dairy farms. In addition, the 2015 annual report of Global Dairy Agenda for Action through the Dairy Sustainability Framework stated that the involvement of dairy farming in sustainable development is the role of the livestock value chain in the economic, social, and environmental cluster dimensions.

The purposes of this study based on this research problem were to identify the sustainability criteria in the value chain of the Greenfields Indonesia dairy farm, to formulate a sustainability strategy of the mega-dairy farm, and to analyze the implementation of Greenfields Indonesia sustainability strategy. The purposes of this study are also expected to contribute to the company in the development of the sustainable business. 
The scope of this study was the company's value chain and the implementation of sustainable dairy farming at GFI under the SAI Platform consisting of 5 dimensions of sustainability for dairy farming: sustainable livestock raise, dairy cattle concerns, economic sustainability, social sustainability, and environmental sustainability. In terms of the scope, this research was based on the descriptive analysis of fuzzy delphi methods and dematel method.

\section{METHODS}

The research was conducted in March 2017. The study was conducted at Greenfields Indonesia, located at Kawi Mountain, Babadan Village, Malang Regency, East Java. This company is one of the dairy farms with the biggest mega dairy farm concept in Indonesia. According to Japfa Group's 2016 Annual Report, GFI dairy farms have a population of 8,416 dairy cows, including 4,553 dairy lactation cows.

Types of data sources were primary and secondary data. Primary data were taken through in-depth interviews with the internal company. In addition, expert opinion assessors from practitioners, the Vice President of IndonesianDairy Farmers Association, and academicians, lecturers of the Faculty of Animal Husbandry IPB. Experts were selected based on knowledge of Greenfields Indonesia and competence on sustainable dairy farming. Expert assessment was assisted by questionnaires from interviews and analysis through the Delphi method. In addition, the secondary data were taken from the company's annual journal and report.

The data obtained in this research were then analyzed using descriptive analysis. The analysis in this research was based on data processing from FDMDEMATEL method, integration of fuzzy delphi method (FDM) and decision-making trial and evaluation laboratory (DEMATEL). The fuzzy delphi method (FDM) is a method that aims to ensure that there is no misinterpretation of expert opinion based on a quantitative assessment (Glumac et al. 2011). The use of methods in this study had significant advantages. Advantages of fuzzy delphi method are timesaving, fewer surveys, increased recovery rates, and assurance of completeness and consistency with the opinions of selected expert groups (Sánchez-lezama et al. 2014). The Fuzzy delphi method in this study was based on the assessment of all internal experts as many as 5 people consisting of Head of Dairy Farm Indonesia, Milking and Herd manager, Industrial Relations Manager, Human Resources and General Affair manager, and Corporate Social Responsibility Executive. Assessment results were converted to fuzzy triangular numbers based on the researcher's suggestion.

Table 2. Variables for weighting interests on criteria

\begin{tabular}{clc}
\hline Level of Interest & \multicolumn{1}{c}{ Variables } & Fuzzy Scale \\
\hline 5 & Very Important & $(0.6,0.8,1.0)$ \\
4 & Important & $(0.4,0.6,0.8)$ \\
3 & Neutral & $(0.2,0.4,0.6)$ \\
2 & Not important & $(0.1,0,2.0,4)$ \\
1 & Very unimportant & $(0.0,0.1,0.2)$ \\
\hline
\end{tabular}

The dematel (decision-making trial and evaluation laboratory) is a methodology that aims to analyze the relationships between decision - making criteria (Garg et al. 2014). The dematel method is a method that can measure effectively the level of mutual influence of various factors and complex causal relationships in decision problems (Yang and Lu, 2012). This method not only can analyze the relation of criterion between cause and effect based on its structural model but also can be used as a method to know the core criterion of linkage relation in a set of criteria (Tseng, 2008). According to $\mathrm{Hu}$ et al. (2009), the initial step for assessment in this method is to determine the level and scale of the evaluation to represent the degree of influence among the criteria. This study based on Yang and $\mathrm{Lu}$ (2012) conducted an assessment on the questionnaire with a scale of values 0 to 3 with a value of 0 as a value that indicates no influence relationship, while the value 3 for the value of the relationship of significant influence. Valuation is the result of the assessment of external experts that have been determined.

Wang et al. (2015) performs data analysis in decisionmaking trial and evaluation laboratory by creating direct relation matrix, which is a decision problem having $\mathrm{n}$ factors evaluated, so then $\mathrm{n} x \mathrm{n}$ relation matrix shows the degree of fixed effect, presented as Z-matrix. Research by Chen (2012) has explained that the analysis of causal diagrams will indicate that the more positive $\mathrm{D}+\mathrm{R}$, the greater the positive value becomes the influence of other factors. A positive D-R indication will affect another factor of negative $D-R$ value. The depiction of cause-and-effect diagrams can be determined from the threshold value of the researcher and expert's agreement. Determination of the value of the threshold should be considered because the smaller the determination of 
the threshold value, the less will affect the complexity of the relationship structure on the causal diagram. Conversely, if too large, then the linkage of criteria on the causal diagram obtained will be less and independent (?) (Li and Tzeng, 2009).

This research is a study that examines the sustainability strategies of Indonesian mega dairy farm. This study is based on the case of Greenfields Indonesia dairy farm that implements sustainability strategies in their business activities. This sustainability strategy analyzes decision making of internal and external experts through fuzzy delphi and dematel methods. The result of the analysis becomes the sustainability strategy needed by Indonesian mega-dairy farm. Research framework in Figure 1.

\section{RESULTS}

\section{Overview Greenfields Indonesia}

Greenfields Indonesia is an integrated dairy business enterprise between dairy farm and dairy processing industry. Dairy farming Greenfields Indonesia has 2 dairy farm sites, located in Gunung Kawi, Babadan Village, Malang Regency, and Ngadirengga, Wlingi, Blitar Regency. The area of dairy farms located in Gunung Kawi has an area of 25 hectares, while the location in Wlingi has an area of 172 hectares. Currently, farms have a total of 8,000 dairy cows with 4,000 lactation cows. This whole lactation cow produces a full-capacity production of 125-tonnes of milk each day to be processed by itself into quality processed dairy products. The company's business must go according to the achievement of the GFI's dairy farm mission of becoming the largest, most modern and best dairy farm in South East Asia by producing fresh and international-quality fresh milk. In addition to running the dairy farm business, Greenfields Indonesia has the following missions: (1) Providing quality fresh and natural milk with respect to sustainable environmental balance, (2) Developing and improving the genetics of dairy cows through a continuous selection process with attention to comfort and welfare of livestock, and (3) Improving the quality and welfare of human resources on an ongoing basis.

The mission of Greenfields Indonesia dairy farm has the purpose of not only conducting business activities that support the profit of farm but also supporting social and environmental conditions. This requires companies to practice sustainable dairy farming. In addition, the company's quality policy on dairy farming of GFI is to become a sustainable livestock that has a core value in doing business in order to have a passion and high regard in quality, integrity, cooperation and commitment to always make continuous improvement, develop and improve the quality of human resources, environmental empowerment, and contribute to the development of dairy industry in Indonesia.

\section{Greenfields Indonesia Business Process}

Greenfields Indonesia's company as a mega-dairy farm has the main goal to produce quality milk. This makes the company's value chain of Greenfields Indonesia has a major activity as a dairy farm and dairy processing industry. Nazir et al. (2014) describe that the value chain is a business model that is able to see the operational activities of the organization to generate an added value of a product or service, so as to produce an organizational competitive power. The integrated business pattern of the dairy farm and dairy industry has advantages in the ease of control to maintain the quality and quantity of milk. Company management has the flexibility in controlling the entire business process to achieve the desired results. Dairy farms have business processes as shown in Figure 2 that are identified based on the value chain.

Business process analysis results based on the company's value chain show that dairy farms GFI controls all business processes to produce the best quality milk in Indonesia. Every business process by GFI produces quality milk required with dairy cow control, environmental control, and expenditure control of company needs. Record of all status or condition of each dairy cows can be known by herd information system (HIS). The use of this system makes it easier to track productivity and the condition of weaning until it is no longer utilized or culled, so the process of cow replacement can be easily executed based on the condition of cow productivity. The feeding decision for a dairy cow is also based on the information from the herd management system according to the production of milk produced. Feeding decisions will also affect the needs of all feeds for livestock, for forage, concentrate, or additional feed. This makes it easier for the procurement department to plan the purchasing needs for the required feed. The whole process is supported by Enterprise Resources Planning (ERP) system through SAP software with standardized management system management process by ISO 9001 . 


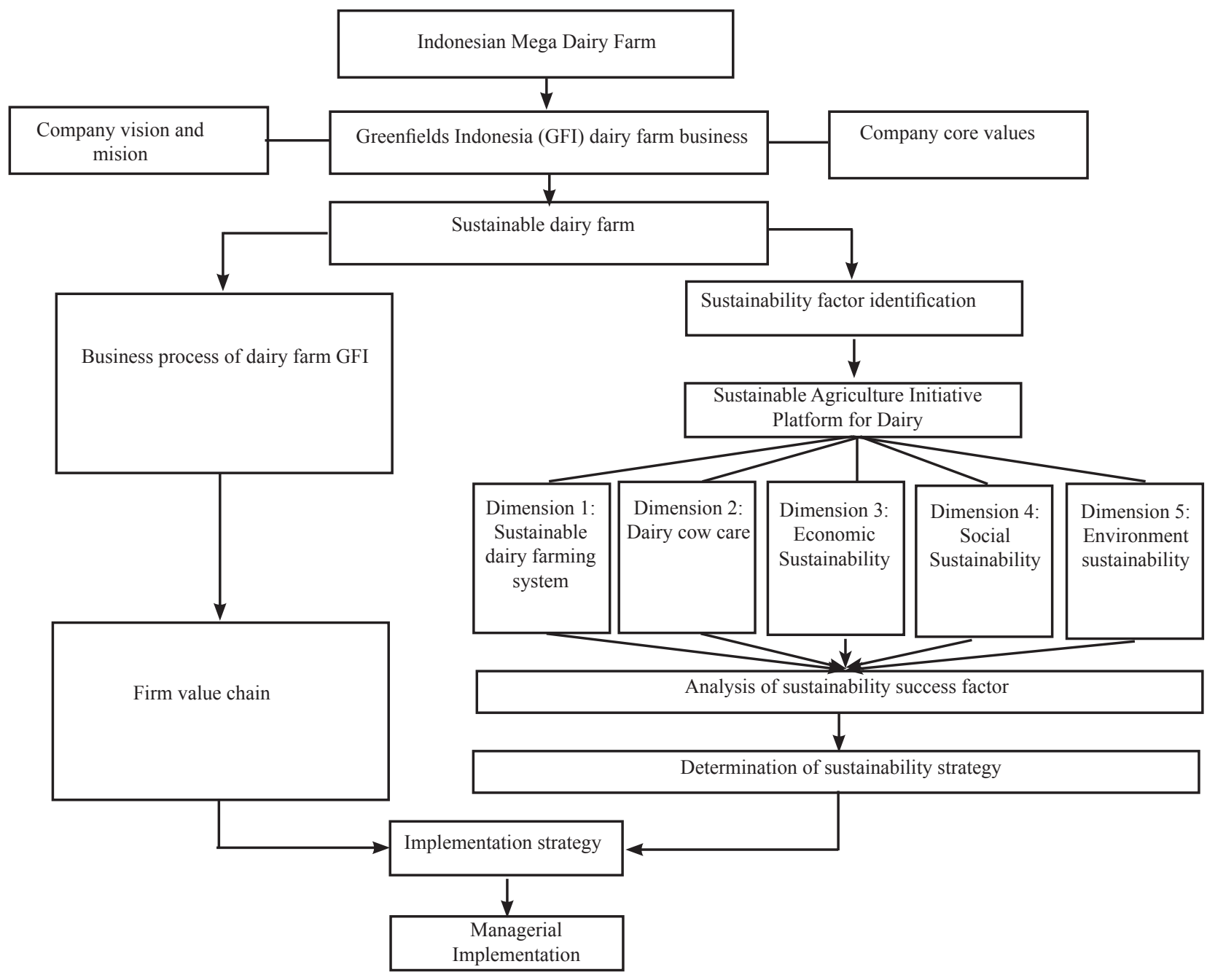

Figure 1. Research framework

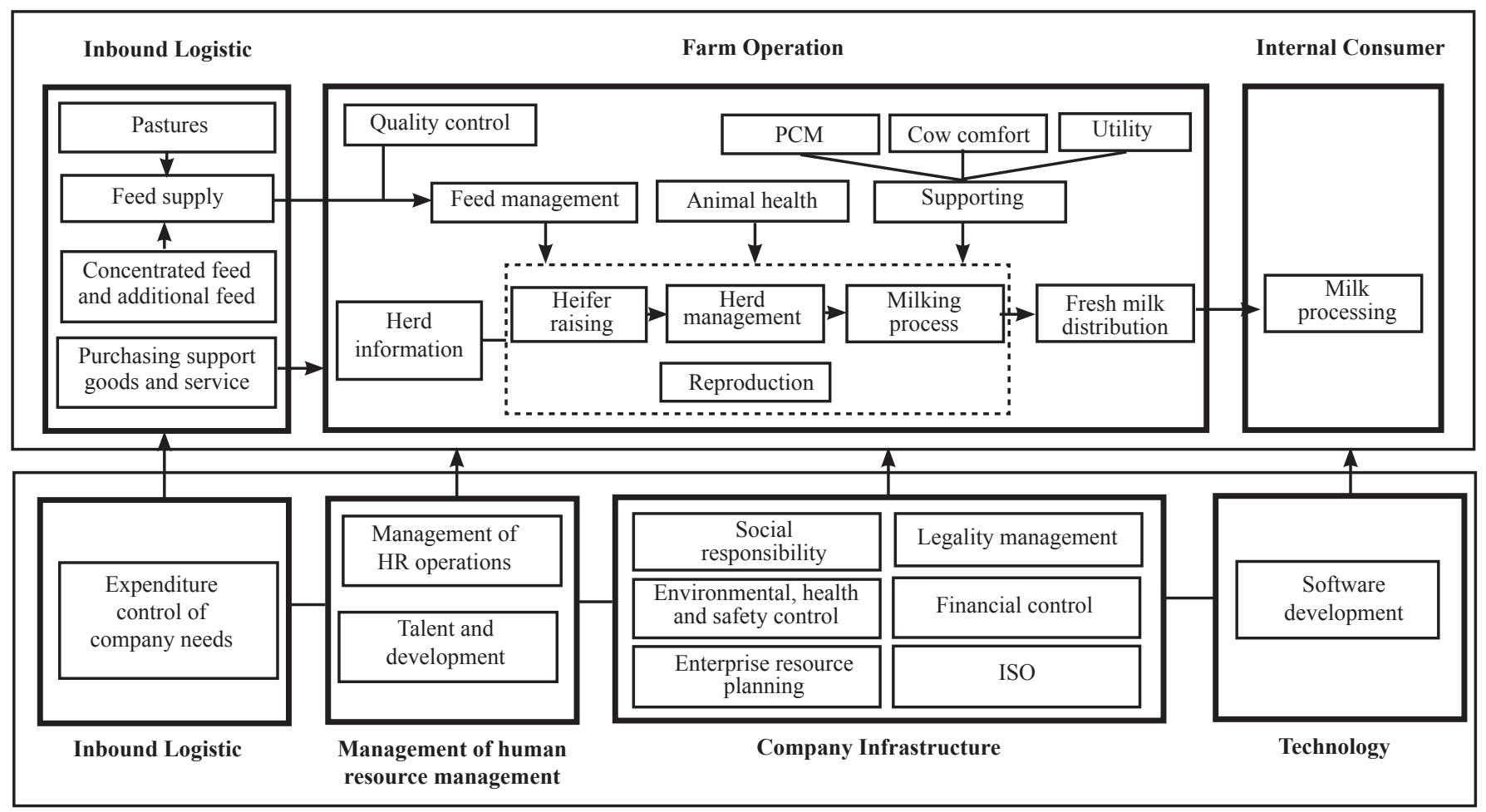

Figure 2. GFI Business Process 


\section{Greenfields Indonesia Sustainability Factors}

GFI sustainable dairy farming pays close attention to 5 important dimensions, including sustainable dairy farming system, dairy cow care, economic sustainability, social sustainability, and environmental sustainability. The results of data processing through fuzzy delphi showed that there were 11 criteria of success factors out of 20 criteria of GFI dairy farm sustainability factors with the similarity of fuzzy 4000 assessment score and the average fuzzy 0.800 (Table 1).

\section{Sustainability Strategy of Mega-Dairy Farm}

The results of the evaluation of GFI sustainable dairy farms were based on the results of Total impact matrix comparison (Table 2). The standardization of company management system criterion (C2) had the highest D-R value and the livestock model criterion $(\mathrm{C} 11)$ had the highest $\mathrm{D}+\mathrm{R}$ score. The value (D-R) criterion $\mathrm{C} 2$ had a value of 0.4584 , while the value $(D+R)$ of 7.8469 was on the criteria of durability model of dairy farms (C11).

Table 1. Identification of success factors criteria for sustainable dairy farm

\begin{tabular}{|c|c|c|c|c|}
\hline \multirow[b]{2}{*}{ Dimension } & \multirow[b]{2}{*}{ Code } & \multirow[b]{2}{*}{ Criteria } & \multicolumn{2}{|c|}{ Score } \\
\hline & & & Fuzzy Evaluation & $\begin{array}{l}\text { Average of } \\
\text { Fuzzy Number }\end{array}$ \\
\hline \multirow[t]{2}{*}{$\begin{array}{l}\text { Sustainable dairy } \\
\text { farming system }\end{array}$} & $\mathrm{C} 2$ & $\begin{array}{l}\text { Standardization of company management } \\
\text { system }\end{array}$ & 4.000 & 0.800 \\
\hline & $\mathrm{C} 4$ & Cooperation of forage supply & 4.000 & 0.800 \\
\hline \multirow[t]{2}{*}{ Dairy cow care } & C6 & Selection and management of dairy breeding & 4.000 & 0.800 \\
\hline & $\mathrm{C} 7$ & $\begin{array}{l}\text { Management of the availability of feed and } \\
\text { drinking water for dairy cow }\end{array}$ & 4.000 & 0.800 \\
\hline \multirow[t]{3}{*}{$\begin{array}{l}\text { Economic } \\
\text { sustainability }\end{array}$} & C9 & $\begin{array}{l}\text { Security, quality, and transparency of produc- } \\
\text { tion activities }\end{array}$ & 4.000 & 0.800 \\
\hline & $\mathrm{C} 11$ & Resilience model of dairy farms & 4.000 & 0.800 \\
\hline & $\mathrm{C} 12$ & Availability of the milk market & 4.000 & 0.800 \\
\hline \multirow[t]{2}{*}{ Social sustainability } & $\mathrm{C} 14$ & Employee training & 4.000 & 0.800 \\
\hline & $\mathrm{C} 15$ & Contributions to local communities & 4.000 & 0.800 \\
\hline \multirow{2}{*}{$\begin{array}{l}\text { Environment } \\
\text { sustainability }\end{array}$} & $\mathrm{C} 18$ & Water use and water quality management & 4.000 & 0.800 \\
\hline & $\mathrm{C} 20$ & Manure Management & 4.000 & 0.800 \\
\hline
\end{tabular}

Table 2. Total impact matrix comparison

\begin{tabular}{lcccc}
\hline \multicolumn{1}{c}{ Criteria } & $\mathrm{D}+\mathrm{R}$ & $\mathrm{D}-\mathrm{R}$ & $\mathrm{D}$ & $\mathrm{R}$ \\
\hline $\mathrm{C} 2$ & 6.7960 & 0.4584 & 3.6272 & 3.1688 \\
$\mathrm{C} 4$ & 4.8743 & 0.1755 & 2.5249 & 2.3494 \\
$\mathrm{C} 6$ & 4.6718 & -0.4277 & 2.1221 & 2.5497 \\
$\mathrm{C} 7$ & 6.6502 & -0.0988 & 3.2757 & 3.3745 \\
$\mathrm{C} 9$ & 5.6674 & -0.0819 & 2.7928 & 2.8747 \\
$\mathrm{C} 11$ & 7.8469 & 0.0538 & 3.9504 & 3.8965 \\
$\mathrm{C} 12$ & 5.5222 & 0.1050 & 2.8136 & 2.7086 \\
$\mathrm{C} 14$ & 5.1732 & -0.1845 & 2.4944 & 2.6789 \\
$\mathrm{C} 15$ & 5.7613 & 0.2869 & 3.0241 & 2.7372 \\
$\mathrm{C} 18$ & 6.3298 & -0.2711 & 3.0293 & 3.3004 \\
$\mathrm{C} 20$ & 7.4311 & -0.0157 & 3.7077 & 3.7234 \\
\hline
\end{tabular}


Evaluation of GFI continuous dairy farms can also be seen in the interaction drawing diagram based on the causal link structure among criteria (Figure 3). Structure visualization causal relationship diagram of the results DEMATEL suggests the threshold value specified by researcher and expert was 0.400 . The determination of this threshold value was against the agreement required to reduce the complexity of decision-making as a sustainability strategy for the dairy farm of GFI. This determination was based on the previous research that the determination of the threshold value was determined by the expert to analyze the supplier development program (Routroy and Kumar, 2014). If the threshold value was too low, the drawing diagram would be too complicated to show the information needed for decision making and if the threshold value was too high then many factors would be presented as independent factors, without showing any relationship with other factors (Li and Tzeng, 2009). Based on this causal diagram, there are seven independent criteria. These independent criteria are $\mathrm{C} 4, \mathrm{C} 6, \mathrm{C} 9, \mathrm{C} 12, \mathrm{C} 4$, $\mathrm{C} 15$, and $\mathrm{C} 18$. This independent criterion indicates that these criteria remain indirectly linked to other criteria (Gandhia et al. 2015).

The positive D-R value stated that the criterion had a greater influence than the other criteria and was assumed to be the top priority, commonly called the dispatcher. Criteria with a negative D-R value received greater influence than other criteria and were assumed to be the last priority, usually called receivers. The value of $\mathrm{D}+\mathrm{R}$ indicates a causal relationship between the criteria with each other, so the greater the value of $\mathrm{D}+\mathrm{R}$, the stronger the relationship between these criteria (Surayya et al. 2013). Based on dematel method in this research, it can be seen that standardization of company management system $(\mathrm{C} 2)$ is the first priority of sustainability of GFI dairy farm at present. The design of sustainability strategy through the system approach in Figure 4 shows the first priority for strategies has a direct effect on the resilience of dairy farm model and manure management, while the resilience of dairy farm model has a mutually influential relationship with manure management. The resilience model of dairy farming also directly manages the availability of feed and water for dairy cows, making GFI concern for dairy cows' care can be maintained.

\section{Implementation Sustainability Strategy of GFI}

The sustainability of the GFI dairy farm business is focused on creating dairy cow care. GFI manages the availability of feed and drinking water by providing ad libitum which is accompanied by efficient delivery. Ad libitum feed and water management are very important because the milk produced is $87 \%$ water and the rest are dry matter (Priska et al. 2013). In addition, feeding and drinking water in ad libitum can guarantee the cow to perform activities naturally. Von Keyserlingk et al. (2009) in his research on the dairy cows' welfare says that that there are 3 categories of dairy cows' welfare, namely categories of health and biological functions, emotional disorders, and natural life. Therefore, efforts to maintain the availability of feed and drinking water is able to create a natural life.

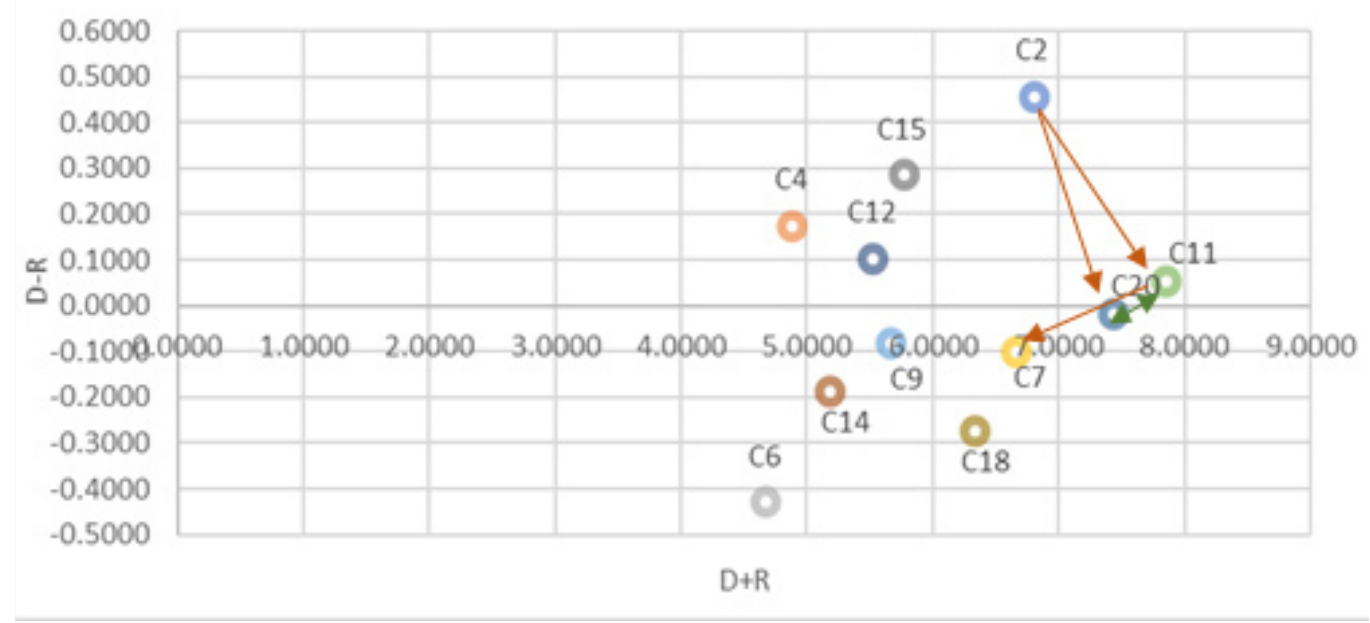

Figure 3. The causal diagram of sustainable dairy farming criteria 
Based on this research also, GFI gives concern to dairy cows' care from the management of feed and drinking water availability capable of producing the best quality milk in Indonesia. Managing the availability of feed and drinking water GFI not only aims for the concern of dairy cows but also maintains the efficient use of feed by clustering dairy cows from nutritional needs based on the traceability of information in the Herd Information System (HIS). Prior research from the technical and economic point of view also shows HIS is able to maintain dairy cows care through ease of reproduction management, animal health control, and improvement of feeding (Leonardi et al. 2013).

Based on the implementation of the strategy in Figure 5, it can be seen that the utilization of manure into biogas for electrical energy has benefits to the environment. The dairy farm with the concept of a mega-dairy farm has the benefit to produce biogas from the number of dairy cow population owned so that the livestock manure can be utilized by the company to be used as electricity consumption in the area of dairy cows. In addition, the importance of contributing to the environment is also caused by the location of farms in the mountains, so it is very critical if there is pollution, especially water pollution. Contributions to the social improvements of surrounding communities dominated by farmers with the provision of liquid fertilizer to farmers are able to increase their crop productivity and impact on partners of the company's forage farmers who can help improve the forage yield to be bought by the company as forage feed. The provision of liquid fertilizer can be useful for the community development as farmers in increasing income from productive crops. Therefore, GFI dairy farm based on mega-dairy farm has the ability in the business process that is viable, bearable, and equitable, so as to create mutual sustainability for society, environment, and company. This sustainability capability is based on Dyllick and Muff (2016) that the current creation of sustainability is more directed towards the sustainable business version 3.0 which is a continuation that changes the perspective of minimizing negative impacts into creating positive impacts relevant to society and the environment. Another approach to sustainability can be directed to create shared value which is a concept that combines contributions to society or the environment with business strategies to create long-term corporate values (Porter and Kramer 2011).

\section{Managerial Implications}

The findings of the research indicate that mega-dairy farms in Indonesia are able to positively contribute not only to domestic milk production contributors in Indonesia, but also to the environmental and social aspects. Therefore, the sustainability strategy of dairy farm mega-dairy farm in Indonesia needs to be proactive, so that the company's environmental and social contribution is also able to increase profits, as well as sustainable corporate competitiveness.

The condition of dairy farmers in Indonesia dominated by rural farmers needs to be given special attention by dairy farm based on mega-dairy farm to run proactive sustainability strategy so that rural farmers can improve the quality and quantity of production. This increase is needed in order to increase domestic milk production so that it can meet the consumption of milk which has an impact on the increase of consumption in Indonesia.

\section{CONCLUSIONS AND RECOMMENDATIONS}

\section{Conclusions}

It can be concluded from this research that GFI dairy farm sustainability consists of 20 criteria of sustainability factor with 11 criteria of sustainability as success factors. These criteria are standardization of company management system, cooperation of forage supply, selection and management of dairy breeding, management of the availability of feed and drinking water for dairy cow, safety, quality, and transparency of production activities, resilience model of dairy farms, availability of the milk market, employee training, contributions to local communities, water use and water quality management, and manure Management. The sustainability strategy of mega-dairy farm based on this criteria relationship structure shows that the standardization of company management system as the first priority can influence the resilience model of dairy farm that depends on the manure management, so as to create sustainability by maintaining the concern of dairy cows' care through the management of the availability of feeding water for dairy cows. The design of GFI sustainability implementation as a mega-dairy farm concept in Indonesia is able to operate with the support of manure treatment through the use of biogas and the provision of liquid fertilizer to farmers, and community empowerment of forage farmers with 
given liquid fertilizer and seeds, and crops that will be purchased by the company for the availability of forage feed in the company.

\section{Recommendations}

Greenfields Indonesia is recommended to be able to empower local dairy farmers by encouraging them to have large-scale dairy farms with standard of Greenfields Indonesia dairy farms. Empowerment can be executed through creating shared value (CSV). Creating shared value, the cluster development of large scale dairy farming, is the best way to encourage companies to be more sustainable.

Recommendation for the next research, comparative research from other mega-dairy farm is urgently needed to strengthen the sustainability strategies needed for dairy farming based on this mega-dairy farm concept. Therefore, further research is expected to compare GFI mega-dairy farm with other mega-dairy farms in Indonesia.

\section{REFERENCES}

Asmara A, Purnamadewi YL, Lubis D. 2016. Keragaan produksi susu dan efisiensi usaha peternakan sapi perah rakyat di Indonesia. Jurnal Management dan Agribisnis 13(1): 14-25. https://doi. org/10.17358/JMA.13.1.14

Chen CA. 2012. Using DEMATEL method for medical tourism development in taiwan. American Journal of Tourism Research 1(1): 26-32.

Dalton J. 2016. Rise of 'mega dairies' could cause crippling health problems for cows, warns charity. http://www.telegraph.co.uk/news/2016/06/01/ rise-of-mega-dairies-could-cause-cripplinghealth-problems-for-c/ [1 October 2017].

Daryanto A. 2017. Daya Saing dan Rantai Nilai Inklusif Industry Peternakan. Bogor: IPB Press.

Dyllick T, Muff K. 2016. Clarifying the meaning of sustainable business: introducing a typology from business-as-usual to true business sustainability. Journal Organization \& Environment 29(2): 156174. https://doi.org/10.1177/1086026615575176

Ford M. 2010. Mega-dairies: Farming solution or big problem? http://edition.cnn.com/2010/TECH/ science /03/15/eco.cow.factory/i ndex .html [10 October 2017].
Gandhia S, Manglab SK, Kumarc P, Kumar D. 2015. Evaluating factors in implementation of successful green supply chain management using DEMATEL: A case study. International Strategic Management Review 3(1-2): 96-109. https://doi.org/10.1016/j.ism.2015.05.001

Garg D, Luthra S, Haleem A. 2014. An evaluation of drivers in implementing sustainable manufacturing in india: using DEMATEL approach. International Journal of Social, Behavioral, Educational, Economic, Business and Industrial Engineering 8(12): 3517-3522.

Hu HY, Lee YC, Lee TM, Tsai CH. 2009. Using BPNN and DEMATEL to modify importanceperformance analysis model: a study of the computer industry. Expert Systems with Applications. 36 (6):9969-9979.https://doi. org/10.1016/j.eswa.2009.01.062.

Ministry of Agriculture. 2016. Outlook susu komoditas pertanian subsektor peternakan [data file]. http://epublikasi.setjen.pertanian.go.id/arsipoutlook/70-outlook-peternakan/414-outlooksusu-2016 [20 September 2017].

Konovalchuk, G, Hanson D, Luloff AE. 2008. Layered community support for sustainable dairy farming. Journal of Extension 46(6): 1-14.

Leonardi S, Marchesi G, Tangorra FM, Lazzari M. 2013. Use of a proactive herd management system in a dairy farm of northern italy: technical and economic results. Journal of Agricultural Engineering 46(2): 208-210.https://doi. org/10.4081/jae.2013.283.

Li CW, Tzeng GH. 2009. Identification of a threshold value for the DEMATEL method using the maximum mean de-entropy algorithm to find critical services provided by a semiconductor intellectual property mall. Expert Systems with Applications 36 (2009): 9891-9898.https://doi. org/10.1016/j.eswa.2009.01.073.

Meul M, Nevens F, Reheul D. 2009. Validating sustainability indicators: focus on ecological aspects of Flemish dairy farms. Ecological Indicators 9(2):284-295. https://doi. org/10.1016/j.ecolind.2008.05.007.

Nazir S, Khan S, Jamil RA, Mehmood QS. 2014. Impact of customer relationship management on customer satisfaction in hoteling industry. Journal of Management Info 3(1): 84-98.https:// doi.org/10.31580/jmi.v3i1.17. 
Routroy S, Kumar CVS. 2014. Analyzing supplier development program enablers using fuzzy DEMATEL. Measuring Business Excellence 18(4):1-26. https://doi.org/10.1108/MBE-082013-0046.

Orhan H, Yasar S. 2010. A model to analyse and classify the level of farmer's qualification in sustainable dairy farming. Journal of Animal and Veterinary Advances 9(1):159-168. https://doi.org/10.3923/ javaa.2010.159.168.

Porter ME, Kramer MR. 2011. The big idea: creating shared value. Harvard Business Review 89(1/2): 62-77.

Priska KL, Waleleng POV, Legrans RAJ, Femi HE. 2013. Analisis break even point (BEP) usaha ternak sapi perah "tarekat MSC" di kelurahan pinaras kota tomohon. Jurnal Zootek 32(1): 158-166.

Sánchez-lezama AP, Cavazos-arroyo J, Albaverahernandez C. 2014. Applying the fuzzy delphi method for determining socio-ecological factors that influence adherence to mammography screening in rural areas of Mexico. Cadernos de Saúde Pública 30(2): 245-258.https://doi. org/10.1590/0102-311X00025113.

Schmalzried HD, Fallon Jr. L F. 2010. Proposed megadairies and quality-of-life concerns: Using public health practices to engage neighbors. Public Health Reports. September-October (125): 754758.
Sulistyati M., Hermawan, Fitriani A. 2013. Potensi usaha peternakan sapi perah rakyat dalam menghadapi pasar global. Jurnal Ilmu Ternak 13(1): 17-23.

Surayya F, Nazaruddin, Siregar I. 2013. Integrasi metode dematel (decision making trial evaluation and laboratory) dan balanced scorecard pada penentuan prioritas pusat distribusi di PT. XYZ. Jurnal Teknik Industri FT USU 3(3): 40-47.

Tseng ML. 2009. Application of ANP and DEMATEL to evaluate the decision-making of municipal solid waste management in Metro Manila. Environmental Monitoring and Assessment 156(1-4):181-97.https://doi.org/10.1007/ s10661-008-0477-1.

Von Keyserlingk MAG, Rushen J, de Passillé AM, Weary DM. 2009. Invited review: the welfare of dairy cattle: Key concepts and the role of science. Journal of Dairy Science 92(9): 41014111.https://doi.org/10.3168/jds.2009-2326.

Wang C, Yang H, Lin S. 2015. To make good decision: a group DSS for multiple criteria alternative rank and selection. Mathematical Problems in Engineering 2015(2015):1-5.https://doi. org/10.1155/2015/813507.

Yang LC, Lu HP. 2012. Applying multiple criteria decision method (MCDM) to evaluate the key factors of a knowledge management system. Information Engineering Letters 2(3): 28-34 